
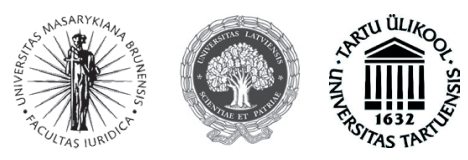

ISSN 1392-6195 (print) ISSN 2029-2058 (online) JURISPRUDENCIJA JURISPRUDENCE 2013, 20(3), p. 1175-1194.

\title{
NEKONKURAVIMO SUSITARIMŲ, SUDAROMŲ TARP DARBDAVIO IR DARBUOTOJO, REGLAMENTAVIMO IR TAIKYMO PROBLEMOS
}

\author{
Tomas Bagdanskis \\ Mykolo Romerio universiteto Teisès fakulteto \\ Verslo teisès katedra \\ Ateities g. 20, LT-08303 Vilnius, Lietuva \\ Telefonas (+370 5) 2714633 \\ Elektroninis paštas tomas@bagdanskis.lt
}

Pateikta 2013 m. rugsèjo 16 d., parengta spausdinti 2013 m. rugsejjo $20 \mathrm{~d}$.

doi:10.13165/JUR-13-20-3-16

Anotacija. Nekonkuravimo susitarimu darbuotojas isipareigoja, pasibaigus darbo sutarciai, sutarta laikotarpi nustatytomis salygomis nekonkuruoti su darbdaviu - nedirbti darbdavio konkurento imoneje, nesteigti imones ar nedalyvauti versle, konkuruojančiame su buvusio darbdavio verslu. Kad sudarytas nekonkuravimo susitarimas bütu pripažistamas galiojanciu, jis turi nepriestarauti istatymui. Lietuvoje nera teises akto, kuris reglamentuotu nekonkuravimo susitarimus tarp darbuotojo ir darbdavio, todel tenka remtis teismu praktika ir teises doktrina. Šios straipsnio tikslas - ivvertinti nekonkuravimo susitarimu sudarymo salygas Lietuvoje ir pateikti rekomendacijas, kaip tobulinti teisini reglamentavima. Nors Lietuvos Respublikos Konstitucijos įtvirtinta, kad kiekvienas žmogus gali laisvai pasirinkti darbą, tačiau teise laisvai pasirinkti darba nevertintina kaip absoliuti - ji negali büti traktuojama kaip garantuojanti, kad kiekvienas asmuo turés darba ar gaus konkretu pageidaujama darba, taip pat ji neužkerta galimybès tam tikrais pagrindais apriboti jos igyvendinima, nustatant atitinkamus pagristus ir teisetus reikalavimus. Darbdaviai suinteresuoti apsaugoti imonès know-how, klientu sąrašus, kainu politika, kitas žinias apie įmonès veikla nuo šiu paslapčiu panaudojimo konkurencijai su jais. Tokia galimybę turi buve darbuotojai, todèl 
darbdaviai siekia su jais sudaryti nekonkuravimo susitarimus. Dél to tik nustačius teisinga kompensacija bei kitas sąlygas už nurodytus darbuotojo teisiu suvaržymus, šie suvaržymai nevertintini kaip neproporcingi ir pažeidžiantys darbuotoju konstitucines teises. Priešingu atveju nekonkuravimas laikytinas ịtvirtinančiu esminę saliu nelygybę ir gali büti pripažintas negaliojančiu, darbuotojui kreipiantis í teismą.

Reikšminiai žodžiai: darbuotojas, darbdavys, nekonkuravimo susitarimai, darbo sutartis, darbo santykiai, civiliniai santykiai.

\section{Ivadas}

Igyvendindami savo interesus asmenys susisaisto ịvairių rūšių teisiniais santykiais, reguliuojamais skirtingų teisės šakų normomis. Vienais santykiais (darbo, rangos) siekia susikurti reikalingas vertybes, kitais (pirkimo-pardavimo, dovanojimo, paveldejjimo) jų igyti, trečiais (kredito, nuomos, panaudos) laikinai perleisti turimas vertybes naudotis kitiems asmenims, ketvirtais (žalos atlyginimo, administraciniais, baudžiamaisiais, procesiniais) - apginti pažeistas savo teises, penktais (politiniais, rinkimų, tarnybiniais, igaliojimo, atstovavimo ir kt.) - igyti valdinius igaliojimus ${ }^{1}$. Iki XIX a. darbo teisinius santykius reguliavo civilinès teisinès normos ${ }^{2}$, o darbo sutartis laikyta viena iš civilinių teisinių sutarčių ${ }^{3}$. Darbo teisinių santykių sąvoka teisès teorijoje atsirado XIX-XX a., tačiau tik antroje praejjusio amžiaus pusejje tapo viena svarbiausių šakinių kategorijų ${ }^{4}$. Darbo teisé vystėsi ir ėmè dominuoti kaip savarankiška teisės šaka. Lietuvoje nuo XX a. penktojo iki devintojo dešimtmečio darbo santykiai buvo vienintelis teisètas būdas užsidirbti, o bet kokia savarankiška veikla buvo ribojama, daugeliu atvejų laikoma prieštaraujančia įstatymams ar net nusikalstama 5 .

Paskutiniaisiais XX a. dešimtmečiais vykstant globalizacijos procesams, turintiems itakos ekonominiams, socialiniams, techniniams, darbo ir jo aplinkos pokyčiams, Vakarų Europoje pradèjo ryškèti naujos tendencijos. Suaktyvẻjus globalizacijos procesams, keičiantis rinkos ekonomikos sąlygoms, transformuojasi ir darbo bei gamybos organizavimo modeliai. Juo sudetingesni žmonių socialiniai santykiai, tuo didesnis poreikis šiuos santykius reguliuoti, t. y. priimti teisès aktus, kurie sudarytų prielaidas spręsti socialinių interesų konfliktus ${ }^{6}$. Taigi iškilo naujo teisinio reglamentavimo poreikis, nes

1 Plačiau apie teisinių santykių rūšis žr. Vaišvila, A. Teisés teorija. Vilnius: Justitia, 2009, p. 438-440.

2 Dambrauskienè, G. Civilinių ir darbo sutarčių sąveika. Jurisprudencija. 2002, 28(20): 7.

3 I darbo sutartị labiausiai panaši buvo paslaugų nuomos sutartis (location-conductio operarum) - pagal šią sutarti, vienas laisvas žmogus (locator) patenka kito (conductor) dispozicijon, t. y. už nustatytą atlyginimą tam tikram laikui parduoda savo darbo jègą, pavyzdžiui, parsisamdo vežiku. Nekrošius, I.; Nekrošius, V.; Vèlyvis, S. Roménu teisè. Vilnius: Justitia, 1999, p. 245.

4 Lushnikov, A. M.; Lushnikov, N. V. Kurs trudovogo pravo. Tom 1. Moskva: Statut, 2009, s. 700-714.

5 Krasauskas, R. Nekonkuravimo susitarimai darbo teisejje. Ar darbuotojas ir darbdavys lygiaverčiai konkurentai? Jurisprudencija. 2008, 8(110): 41-49.

6 Tatol, R. Nekonkuravimo susitarimų su įmoniu darbuotojais sudarymo tvarka ir igyvendinimas. Societal Innovations for Global Growth. 2012, (1): 949-961. 
tradiciniai darbo teisès reguliuojami santykiai neapima naujų veiklos modelių. Taigi dẻl vis ryškiau pasireiškiančių skirtingų teisės šakų integracinių procesų kyla painiava atskiriant darbo ir civilinius teisinius santykius. Darbo teisinių santykių ir civilinių teisinių santykių panašumai apsunkina konkrečios teisės šakos normų pasirinkimą taikant jas susiklosčiusiems santykiams. Suprasti ir tinkamai identifikuoti teisinius santykius, kylančius tarp atskirų subjektų, labai svarbu tiek teoriniu, tiek praktiniu požiūriu. Pirma, skirtingi teisiniai santykiai skirtingai reguliuojami, jiems taikomos skirtingos teisès normos, atitinkamai iš to kyla skirtingos teisès ir pareigos, šalių interesų apsaugos mechanizmai. Antra, kad tarp sutarties šalių ir / arba valstybės, kaip santykių reguliacinių priemonių leidèjo ir administratoriaus, nekiltų ginčų dèl santykių kilmès, turinio, teisètumo ir pagrịstumo.

Atsiranda lanksčios užimtumo formos, nestandartiniai darbo santykiai, formuojasi vadinamoji pilkoji ekonomikos zona. Šalia standartinių darbo santykių darbo rinkoje atsiranda nestandartiniai santykiai ir nestandartiniai susitarimai, pavyzdžiui, nekonkuravimo susitarimai, konfidencialumo susitarimai, siuntimo studijuoti ar kelti kvalifikaciją susitarimai, kur atsiranda klausimai: kokios teisès šakos normos turi būti taikomos: darbo teisès ar civilinès teisès?

Šio straipsnio tikslas - apžvelgti nekonkuravimo susitarimų, sudaromų tarp darbdavio ir darbuotojo, taikymo praktiką ir aiškinimą Lietuvos teismuose bei suformuluoti rekomendacijas dèl jų turinio, kad tokie susitarimai būtų galiojantys.

Tyrimo uždaviniai:

- Pateikti mokslinę nuomonę, kokios teisès šakos reguliavimui priskirtini nekonkuravimo susitarimai;

- Ivertinti nekonkuravimo susitarimų rūšis bei turinị galiojimo prasme;

- Pateikti pasiūlymus dèl teisinio reglamentavimo, susijusio su nekonkuravimo susitarimų tarp darbuotojo ir darbdavio sudarymu, ir rekomendacijas dèl tokių susitarimų turinio.

Lietuvos teisès doktrinoje nekonkuravimo susitarimų tarp darbdavio ir darbuotojo problematika nagrinèta T. Davulio ${ }^{7}$, R. Krasausko ${ }^{8}$, R. Tatol ${ }^{9}$, A. Petravičiūtès ${ }^{10}$, tačiau dèl teisinio reguliavimo spragų ir negausios teismų praktikos ši tema aktuali. Svarbu akcentuoti, kad pasikeitusi ekonominè-socialinè aplinka, kai rinka tampa globalesnè ir konkurencija versle vis didèja, darbo teisès reguliavimo objektas tai plečiasi, tai siaurèja, o nekonkuravimo susitarimai tampa labai aktualūs. Be to, besikeičianti teisminė praktika tampa pagrindiniu šaltiniu nustatant, kaip tokie nekonkuravimo susitarimai turètų būti taikomi praktikoje, nes Lietuvos teisèje jie nėra reglamentuoti. Paminètina, kad nekonkuravimo susitarimus verslo perleidimo atveju nagrinèjo V. Bité ${ }^{11}$. Taigi

7 Davulis, T. Nekonkuravimo susitarimai Lietuvos darbo teisėje. Juristas. 2006, 4.

8 Krasauskas, R., supra note 5, p. 41-49.

9 Tatol, R., supra note 6, p. 949-961.

10 Petravičiūtè, A. Nekonkuravimo susitarimai tarp darbuotojo ir darbdavio: esmè ir teisinio reguliavimo ypatumai. Teisé. 2007, 65: 144-150; Tiažkijus, V. Darbo teisé: teorija ir praktika. Vilnius: Justitia, 2005.

11 Bite, V. Non-Competition convenants in case of a business transfer. Jurisprudencija. 2011, 18(1): 177198. 
ekonominiai ir socialiniai santykiai greitai keičiasi, sukurdami teisinio reglamentavimo spragas bei teisès normų taikymo problemas, taip pat keičiasi ir teismų praktika, todèl ši tema aktuali.

Tiriant taikyti ịvairūs mokslinio pažinimo metodai: loginès analizès, sisteminès analizès, sintezès, lingvistinis (gramatinis), lyginamasis, lyginamasis istorinis ir genetinis.

\section{Nekonkuravimo susitarimai - kokios teisès šakos reguliavimo objektas?}

Nekonkuravimo susitarimu darbuotojas įsipareigoja, pasibaigus darbo sutarčiai, sutartą laikotarpį nustatytomis sąlygomis nekonkuruoti su darbdaviu - nedirbti darbdavio konkurento įmonejje, nesteigti įmonès ar nedalyvauti versle, konkuruojančiame su buvusio darbdavio verslu. Kad sudarytas nekonkuravimo susitarimas būtu pripažịstamas galiojančiu, jis turi neprieštarauti ịstatymui.

Akcentuotina, kad šiuo metu Lietuvoje nèra teisès akto, kuris reglamentuotų nekonkuravimo susitarimus tarp darbuotojo ir darbdavio, nors LAT pripažįsta, kad tokie susitarimai galimi. Lietuvos Respublikos darbo kodekso ${ }^{12}$ (toliau - DK) 9 straipsnio 2 dalyje nustatyta galimybè pasinaudoti teisès analogija, t. y. pagal darbo ịstatymų pradmenis ir prasmę taikyti kitų teisès šakų normas, reglamentuojančias panašius santykius. Lietuvos Respublikos civilinio kodekso ${ }^{13}$ (toliau-CK) 2.164 straipsnyje numatoma, jog prekybos agentas ir atstovaujamasis gali sutartyje numatyti, kad, pasibaigus sutarčiai, prekybos agentas ne daugiau kaip dvejus metus nekonkuruos su atstovaujamuoju. Konkurencijos ribojimas gali būti apibrèžtas tik tam tikra teritorija ir prekių ar paslaugų rūšimis arba klientų grupe ir teritorija, kurios prekybos agentui buvo patikètos. Prekybos agentas turi teisę ị kompensaciją už visą konkurencijos draudimo laikotarpị, kurios dydis gali būti apibrèžiamas metine prekybos agento atlyginimo suma. Tai Lietuvos Respublikos teisės aktuose yra iš esmės vienintele nuostata, susijusi su nekonkuravimu, kuri kaip analogija galètų būti taikoma nekonkuravimo susitarimams tarp darbuotojo ir darbdavio.

Lietuvos Respublikos Konstitucijos 48 straipsnio 1 dalyje inter alia įtvirtinta, kad kiekvienas žmogus gali laisvai pasirinkti darbą bei verslą ir turi teisę gauti teisingą apmokèjimą už darbą. Laisvè pasirinkti darbą ir verslą reiškia, kad kiekvienas žmogus turi konstitucinę teisę pats spręsti, kokią veiklą jam pasirinkti. Ši nuostata remiasi visuotinai pripažinta žmogaus laisvès koncepcija. Teisẻ laisvai pasirinkti darbą ar verslą yra viena iš būtinų sąlygų žmogaus, asmenybès gyvybiniams poreikiams tenkinti, deramai padèčiai visuomenèje užimti ${ }^{14}$.

12 Lietuvos Respublikos darbo kodeksas. Valstybès žinios. 2002, Nr. 64-2569.

13 Lietuvos Respublikos civilinis kodeksas. Valstybès žinios. 2000, Nr. 74-2262.

14 Lietuvos Respublikos Konstitucinio Teismo 2002 m. kovo 14 d. nutarimas [interaktyvus]. [žiūrèta 201306-16]. <http://www.lrkt.lt/dokumentai/2002/n020314.htm>; Lietuvos Respublikos Konstitucinio Teismo 2002 m. lapkričio 25 d. nutarimas [interaktyvus]. [žiūrèta 2013-06-16]. <http://www.lrkt.lt/dokumentai/2002/n021125.htm>. 
Teisè laisvai pasirinkti darbą nevertintina kaip absoliuti - ji negali būti traktuojama kaip garantuojanti, kad kiekvienas asmuo turès darbą ar gaus konkretų pageidaujamą darbą, taip pat ji neužkerta galimybès tam tikrais pagrindais apriboti jos ịgyvendinimą, nustatant atitinkamus pagrisstus ir teisètus reikalavimus. Dirbdamas darbą, darbuotojas igyja ar pagerina savo kvalifikaciją, profesines žinias ir igūdžius. Aukštesnè profesinė kvalifikacija sudaro prielaidas jam geriau konkuruoti darbo rinkoje, pretenduoti ị didesnị atlyginimą už darbą, taigi ji yra reikšmingas veiksnys, pagerinantis sąlygas darbuotojui ịgyvendinti savo teisę pasirinkti konkretų pageidaujamą darbą bei už darbą gauti teisingą atlyginimą. Darbdaviai suinteresuoti apsaugoti įmonės komercines ar technologines paslaptis ir kitą konfidencialią informaciją (know-how, klientų sąrašai, kainų politika, kitos žinios apie ịmonės veiklą, kt.) nuo šių paslapčių panaudojimo konkurencijai su jais. Tokią galimybę turi buvę darbuotojai, todèl darbdaviai siekia su jais sudaryti nekonkuravimo susitarimus. Tokie susitarimai neišvengiamai riboja juos pasirašiusių darbuotojų teisę laisvai pasirinkti darbą bei verslą. Tiek pakankama darbdavio turtinių interesų apsauga, tiek darbuotojo darbo teisių apsauga - būtinos normalios ūkinès veiklos šiuolaikinèje visuomenèje prielaidos ${ }^{15}$.

Teisès teoretikai ir praktikai diskutuoja, kokia teisės šaka turètų reguliuoti šiuos santykius - darbo teisè ar civilinė teisè?

Darbo teisès mokslininkai Lietuvoje nekonkuravimo susitarimus linkę priskirti darbo teisès reguliavimo sričiai. Pavyzdžiui, prof. T. Davulis teigia, kad tokių susitarimų negalima aiškinti atsietai nuo darbo sutarties. Be to, nekonkuravimo susitarimo galiojimas faktiškai pasibaigus darbo santykiams negali paversti tokio susitarimo civiline sutartimi, nes nekonkuravimo susitarimų conditio sine qua non yra darbo santykiai, iš kurių išplaukia nevienoda sutarties šalių padėtis, dèl kurios apskritai egzistuoja darbo santykiai ${ }^{16}$. Doc. R. Krasauskas laikosi dar aiškesnès pozicijos: tiek sudarant nekonkuravimo susitarimus, kuriais yra ribojama konstitucinė žmogaus teisè laisvai pasirinkti darbą, tiek juos vykdant tarp darbuotojo ir darbdavio susiklosto darbo teisiniai santykiai, todèl aiškinant šiuos susitarimus, visų pirma, turi būti taikomi darbo įstatymai. Norint ịteisinti galimybę darbuotojams ir darbdaviams nekonkuravimo susitarimais susitarti dèl kai kurių konstitucinès teisès laisvai pasirinkti darbą ribojimų, turètų būti papildytas Darbo kodeksas įtvirtinant nuostatas dẻl tokių susitarimų sudarymo, vykdymo ir nutraukimo. Tai darydamas įstatymų leidèjas visų pirma turètų paisyti Konstitucijoje ir Konstitucinio Teismo oficialioje doktrinoje nurodytų imperatyvų ${ }^{17}$.

Tačiau teismai nuo 2007 metų aiškiai nekonkuravimo susitarimą laiko civilinès teisès reguliavimo objektu.

Pabrěžtina, kad iki tol, t. y. 2005 metais, buvo viena Lietuvos Aukščiausiojo Teismo (toliau - LAT) nutartis, kurioje užsiminta, kad tai patenka i darbo teisès reguliavimo sritį: LAT nekonkuravimo sąlygą vertino remdamasi darbo teisès normomis. LAT pripažino, kad tarp darbdavio ir darbuotojo susiklostę visuomeniniai santykiai, kuriuos

15 LAT 2013 m. liepos 5 d. nutartis civilinejje byloje $U A B$,,Marilita “ v. A. B. ir R. Č. Nr. 3K-3-401/2013.

16 Davulis, T., supra note 7, p.12.

17 Krasauskas, R., supra note 5. 
reguliuoja nekonkuravimo susitarimai, yra darbo santykiai, ir konstatavo, kad darbo sutarties sąlygos, nustačiusios konkurencijos draudimą bei kompensaciją už ji, neprieštaravo įstatymams (Darbo sutarties įstatymui ir jo 8 straipsnio 3 daliai ${ }^{18}$ ) ir buvo privalomos sutarties šalims ${ }^{19}$.

Šiuo metu nekonkuravimo susitarimas kasacinio teismo praktikoje laikomas civiliniu teisiniu sandoriu nepaisant to, kad jis sudarytas darbo sutarties šalių ir inkorporuotas ị šalių sudarytą darbo sutartị kaip jos papildymas, atsižvelgiant ị sutarčių laisvės principą, suteikiantị teisę šalims laisvai sudaryti sutartis ir savo nuožiūra nustatyti tarpusavio teises bei pareigas, taip pat ir Civiliniame kodekse nenumatytas, jeigu tai neprieštarauja i̊statymams (CK 6.156 straipsnio 1 dalis). Lietuvos Aukščiausiasis Teismas, pasisakydamas dèl nekonkuravimo susitarimo darbo teisiniuose santykiuose, yra konstatavęs, kad nagrinejjamam susitarimui pagal įstatymo analogiją taikytinas CK 2.164 straipsnis, reglamentuojantis konkurencijos draudimą, taip pat CK šeštosios knygos II dalies „Sutarčių teisė" normos, CK 1.5 straipsnis. Pažymètina, kad CK 2.164 straipsnis, sprendžiant bylas dẻl nekonkuravimo susitarimų, taikomas atsižvelgiant ị juos sudarančių šalių ir susitarimų ypatumus, kuriuos lemia pirmiau išdėstytos Konstitucijos normos ${ }^{20}$.

Mūsų nuomone, reiktų skirti du momentus: nekonkuravimo draudimas, kai egzistuoja darbo teisiniai santykiai, ir nekonkuravimo draudimas, kai darbo santykiai yra pasibaigę.

Pirmuoju atveju manytina, kad nekonkuravimo draudimas turètu patekti į darbo teisès reguliavimo sriți, nes darbuotojas vykdydamas pareigas privalo būti sąžiningas ir lojalus darbdaviui. Tokiu atveju, neplečiant nekonkuravimo apimties, darbas pas konkurentą iš esmès būtų darbo drausmès pažeidimas, reguliuojamas darbo teisès normų. Tą patvirtina ir teismų praktika. Apygardos teismas pripažino, kad darbuotoją ir darbdavị sieja pasitikejimo santykiai, kad darbuotojas turi būti lojalus darbdaviui. Su tokia teismo išvada reikia sutikti. Taigi kyla pagrịstų abejonių, ar darbuotojas būtų lojalus ir darbdavys juo pasitiketų, jeigu darbuotojas tuo pačiu metu dirbtų ir su darbdaviu konkuruojančioje įmonèje ${ }^{21}$.

Antruoju atveju, kai darbo santykiai pasibaigę, nelaikytume tokio susitarimo darbo teisès reguliavimo objektu. Mūsų nuomone, tikslingiausia netgi būtų tokias nekonkuravimo susitarimo sudarymo sąlygas nustatyti Lietuvos Respublikos konkurencijos įstatyme, kaip įstatyme, kuris saugo sąžiningos konkurencijos laisvę. Tokiu atveju išvengtume diskusijos, ar Civilinis kodeksas, ar Darbo kodeksas tai turi reglamentuoti. Juk prisiminkime, kad nebegaliojantis Prekybos įstatymas ${ }^{22}$ numate tam tikras nekonkuravimo susitarimų sudarymo sąlygas (1995 m. buvo priimtas Lietuvos Respublikos prekybos îstatymas, kurio 12 straipsnyje numatyta galimybè taikyti konkurencijos draudimą prekybos tarnautojams (pagal šį įstatymą, prekybos tarnautoju buvo laikomas samdomas darbuotojas, kurio darbas tiesiogiai susijęs su prekių pirkimu, laikymu, pardavimu ir

18 Lietuvos Respublikos darbo sutarties įstatymas. Valstybès žinios. 1991, Nr. 36-973.

19 LAT $2005 \mathrm{~m}$. vasario $14 \mathrm{~d}$. nutartis civilinejje byloje $U A B$,,Filana” v. R. J. J. Nr. 3K-3-65/2005.

20 Supra note 15.

21 Supra note 19.

22 Lietuvos Respublikos prekybos ịstatymas. Valstybès žinios. 1995, Nr. 10-204. 
šių operacijų apskaita; prie jų nepriskiriami pagalbiniai darbuotojai). Darbdavys su priimamu į darbą prekybos tarnautoju galèjo sudaryti atskirą sutarti, kad, nutraukęs darbo sutartị, šis nekonkuruos su jo įmone. Pagal Prekybos įstatymą, toks draudimas negalejo trukti ilgiau nei vienerius metus po to, kai nutraukta darbo sutartis, ir per ši laikotarpi darbuotojui buvo privaloma mokèti susitarime nustatyto dydžio kompensaciją), o bandymas nekonkuravimo susitarimus reglamentuoti Darbo kodekse ${ }^{23}$ baigési nesėkmingai, nes Lietuvos Respublikos Seimo kanceliarijos Teisès departamentas ${ }^{24}$ ir Europos teisès departamentas $^{25}$ matė riziką, kad toks reglamentavimas pažeis Lietuvos Respublikos Konstitucijos 48 straipsnị ir Europos Bendrijos sutarties nuostatas. Kadangi pagal Konstituciją riboti žmogaus teises ir laisves galima, jeigu yra laikomasi šių sąlygų: tai daroma įstatymu; ribojimai yra būtini demokratineje visuomenèje siekiant apsaugoti kitų asmenų teises bei laisves ir Konstitucijoje įtvirtintas vertybes, taip pat konstituciškai svarbius tikslus; ribojimais nėra paneigiama teisių ir laisvių prigimtis bei jų esmé; laikomasi konstitucinio proporcingumo principo, manytume, kad LAT praktika, pripažindama sutarčių laisvés principą ir pasiremdama Civilinio kodekso normomis, nepaneigè konstitucinès teisès laisvai pasirinkti darbą, dar kartą patvirtindama, kad konstitucinės teisès nèra absoliučios.

\section{Nekonkuravimo susitarimų rūšys}

Nekonkuravimo susitarimų praktikoje sudaroma vis daugiau, nes rinkoje didejja konkurencija. Patys nekonkuravimo susitarimai pagal atlygintinumo požymį irgi sudaromi ịvairūs. Juos galima būtų klasifikuoti taip (pagal praktikoje pasitaikantị jų turinị atlygintinumo aspektu):

1. Kai numatyta kompensacija;

2. Kai nenumatyta kompensacija.

Tais atvejais, kai kompensacija numatoma, susitarimus galima klasifikuoti taip:

1. Kai kompensacija ịskaičiuota ị darbo užmokestį;

2. Kai kompensacija mokama prie darbo užmokesčio darbo santykių metu;

3. Kai kompensacija mokama darbo santykiams pasibaigus;

4. Mišrūs atvejai, kai dalis kompensacijos sumos mokama darbo santykių metu, dalis pasibaigus darbo santykiams.

Pažymėtina, kad atlygintumo svarba labai didelè, nes nenustačius kompensacijos, tokie susitarimai pripažįstami negaliojančiais.

23 Lietuvos Respublikos darbo kodekso projektas. 2003, Nr. IXP-2593 [interaktyvus]. [žiūrèta 2013-06-16]. $<\mathrm{http}: / /$ www3.1rs.lt/pls/inter2/dokpaieska.showdoc_l?p_id=211505>.

24 Lietuvos Respublikos Seimo kanceliarijos Teisès departamento 2003 m. gegužès 28 d. išvada Nr. IXP-2593 [interaktyvus]. [žiūrèta 2013-06-16]. <http://www3.lrs.lt/pls/inter3/dokpaieska.showdoc_1?p_id=21178>.

25 Europos teisès departamento prie Lietuvos Respublikos Vyriausybės 2003 m. rugpjūčio 5 d. išvada Nr. IXP-2593 [interaktyvus]. [žiūrèta 2013-06-16]. <http://www3.lrs.lt/pls/inter3/dokpaieska.showdoc_ 1?p_id=219891>. 


\section{Nekonkuravimo susitarimų turinys}

Skirtingos nekonkuravimo susitarimų rūšys didina šių susitarimų negaliojimo riziką. Remdamiesi Lietuvos Aukščiausiojo Teismo praktika ir užsienio doktrina, galime suformuoti rekomendacijas, kurios padètų išvengti klaidų, sudarant nekonkuravimo susitarimus. Taigi, sudarant nekonkuravimo susitarimus reikia atkreipti dèmesị ir rekomenduojama susitarti dèl šių sąlygų:

- nustatyti sąžiningą ir teisingą kompensaciją, ịskaitant jos dydị bei mokèjimo tvarką;

- įvertinti darbuotojų, su kuriais tokie susitarimai gali būti sudaromi, požymius, t. y. jų darbo funkcijas, pareigų apimtị, atsakomybės sritis (pavyzdžiui, ar eina vadovaujančias pareigas, ar plètoja ryšius su klientais, ar išmano verslo know-how ir t. t.);

- nustatyti nekonkuravimo susitarimo galiojimą laiką;

- nustatyti nekonkuravimo susitarimo galiojimo apimti (teritorija, prekių ar paslaugų rūšis, klientų grupè, kt.);

- ịsivertinti nekonkuravimo susitarimo formą (paprasta rašytine forma arba tvirtinant notarui);

- nustatyti nekonkuravimo susitarimo nutraukimo atvejus (galimybè šį susitarimą nutraukti darbdaviui, darbuotojui, taip pat darbuotojo atleidimo iš darbo pagrindo įtaka nekonkuravimo susitarimo galiojimui);

- nustatyti sankcijas už nekonkuravimo susitarimo nesilaikymą.

Kasacinis teismas formuojamoje teismų praktikoje dèl nekonkuravimo susitarimų yra nurodęs, kad tokie susitarimai turi atitikti teisingumo, protingumo ir sąžiningumo reikalavimus. Nekonkuravimo susitarimai, atsižvelgiant ị jų tikslus, interesų teisètumą, negali būti sudaromi su bet kuriuo darbuotoju. Susitarime, be kita ko, turi būti nustatyta pusiausvyra tarp abiejų jos šalių interesų, vienos šalies (darbdavio) interesas turi būti ginamas kuo mažiau suvaržant kitos šalies (darbuotojo) veiksmus, šios naudai nustatant tinkamą ir teisingą kompensaciją (žr., pavyzdžiui, Lietuvos Aukščiausiojo Teismo Civilinių bylų skyriaus teisèjų kolegijos $2007 \mathrm{~m}$. spalio $22 \mathrm{~d}$. nutartį civilinejje byloje $U A B$ „Docpartner" v. L. V. Nr. 3K-3-415/2007; 2012 m. lapkričio 12 d. nutarti civilinèje byloje R. S. v. UAB ,ETB Legal“" Nr. 3K-3-476/2012)26.

Vienas iš svarbiausių kriterijų, nustatant, ar nekonkuravimo susitarimas bus galiojantis ar ne, yra sąžiningos kompensacijos darbuotojui nustatymas.

\section{Dèl sąžiningos ir teisingos kompensacijos}

Kadangi darbdavio ir darbuotojo sudaromu nekonkuravimo susitarimu apribojama Konstitucijos 48 straipsnio 1 dalyje įtvirtinta teisè laisvai pasirinkti darbą ar verslą būtent toje srityje, kurioje darbuotojas turi aukštesnę kvalifikaciją, kartu ribojama jo galimybè gauti didesnes nei kitose srityse pajamas, už ịsipareigojimą nekonkuruoti turi būti 
teisingai atlyginama. Dẻl to tik nustačius teisingą kompensaciją už nurodytus darbuotojo teisių suvaržymus, šie suvaržymai nevertintini kaip neproporcingi ir pažeidžiantys darbuotojų konstitucines teises. Priešingu atveju nekonkuravimas laikytinas įtvirtinančiu esminę šalių nelygybę ir gali būti pripažintas negaliojančiu CK nustatytais sandorių negaliojimo pagrindais, vienai iš šalių kreipiantis ị teismą. Atsakovas, gindamasis nuo ieškinio, turi įrodyti, kad ieškovui buvo tinkamai atlyginta už jo teisių suvaržymą.

Europos Sajungos šalių praktika dèl kompensacijų dydžio už nekonkuravimo laikotarpi yra skirtinga. Vienose šalyse (pavyzdžiui, Italijoje, D. Britanijoje, Prancūzijoje) minimalus kompensacijos dydis įstatymuose neapibrěžtas, kitose - nustatyta, kad ši kompensacija, pavyzdžiui, turi būti ne mažesnè kaip 25 procentai buvusio atlyginimo (Lenkijos darbo kodekso $101^{2}$ straipsnio 3 dalis) arba ne mažesnè kaip 50 procentų (Čekijos darbo kodekso 310 straipsnis, Vokietijos komercinio kodekso 74 straipsnis, Belgijos darbo sutarčių įstatymo 65 straipsnis). Lietuvos Respublikos teisès aktuose konkretus minimalus kompensacijos dydis nenustatytas, pagal bendrasias normas jis neturi pažeisti CK 1.5 straipsnyje įtvirtintų principų. Nustatant kompensacijos dydị per ménesị turi būti atsižvelgiama ị tai, kad nekonkuravimo susitarimu apribojama asmens galimybė gauti pajamų pragyvenimui, taip pat ị ribojimų apimtị bei kitas kiekvienu konkrečiu atveju reikšmingas aplinkybes. LAT $2013 \mathrm{~m}$. birželio mèn. nutartimi (byla $U A B$ „JG reklamos dovanos “ v. D. S. ir UAB , Verslo inkorporacijos centras “) konstatavo, kad tarp darbdavio ir darbuotojo sudaryti nekonkuravimo susitarimai yra negaliojantys, jei darbuotojui nėra mokama teisinga ir sąžininga kompensacija. Nors šis principas dẻl teisingos kompensacijos dydžio ir anksčiau buvo atskleistas teismų praktikoje, ši kartą LAT atskleidè konkretesnius kompensacijai keliamus reikalavimus. Minètoje byloje darbuotojui mokèta kompensacija - 9 procentai nuo atlyginimo vidurkio, kas faktiškai sudarė 300 litų per mėn. - buvo pripažinta per maža, kad ją būtų galima laikyti sąžiningu ir teisingu atlygiu už nekonkuravimo susitarime nustatytą plačią ribojimų apimtị - darbuotojui įsipareigojant neužsiimti jokia su darbdaviu konkuruojančia veikla, įskaitant ir darbų atlikimą ar paslaugų teikimą konkuruojančia veikla užsiimančiam asmeniui. Lietuvos Respublikos teisès aktuose konkretus minimalus kompensacijos dydis nenustatytas. Atsižvelgiant ị bendrąsias teisès normas, jis neturi pažeisti CK 1.5 straipsnyje įtvirtintų principų. Nustatant kompensacijos dydị per mėnesị turi būti įvertinama tai, kad nekonkuravimo susitarimu apribojama asmens galimybè panaudojant igytą kvalifikaciją ir sukauptą darbo patirti gauti pajamų pragyvenimui, taip pat į ribojimų apimtị bei kitas kiekvienu konkrečiu atveju reikšmingas aplinkybes. Tai sudaro pagrindą pripažinti, kad susitarimai, kuriais, be teisingo atlyginimo suvaržant konstitucinę teisę laisvai pasirinkti darbą ar verslą, ịtvirtinta esminè šalių nelygybė, neatitiko teisingumo, proporcingumo ir sąžiningumo principų (CK 1.5 straipsnis), prieštaravo imperatyviosioms įstatymo normoms, todèl yra negaliojantys ab initio (CK 1.80 straipsnis). Nagrinėjamu atveju tiek procentinè kompensacijos išraiška, tiek absoliutus jos dydis (mažesnis nei minimali ménesinė alga) yra akivaizdžiai per maži, kad būtų galima kompensaciją laikyti sąžiningu ir teisingu atlyginimu už nekonkuravimo susitarime nustatytos apimties ribojimą ${ }^{27}$. 
LAT byloje ( $U A B$, „Marilita“ v. A. B. ir R. Č.) išaiškino, kad kompensacija už nekonkuravimą negali būti ịtraukta ị darbo užmokestị, nes darbo užmokestis yra atlyginimas už darbą, darbuotojo atliekamą pagal darbo sutartį. Teismas aiškiai nustatė, jog susitarimas dèl kompensacijos už nekonkuravimo įsipareigojimą turi būti aiškiai išreikštas apibrěžiant jos dydi ir paskirtį, taip pat atskiriant kompensaciją nuo sutartų kitos paskirties mokèjimų ${ }^{28}$.

Taigi pagal teismų praktiką esant plačiai nekonkuravimo įsipareigojimo apimčiai, iki 10 procentų darbo užmokesčio sudaranti arba mažesnè už minimalų darbo užmokestị kompensacija nėra laikoma pakankama ir gali būti pagrindas pripažinti tokí nekonkuravimo susitarimą negaliojančiu. Atkreiptinas dėmesys, kad LAT paminèjo minimalios mėnesinè algos kategoriją, kuri galètų būti kaip pagrindas sprendžiant, kiek kompensacija teisinga, kiek neteisinga.

Asmenys, siekdami tam tikrų tikslų ir sudarydami sandorius, laisvai sprendžia dèl savo teisių ir pareigų, tačiau sutarties laisvès principas, kaip ir kiti bendrieji teisès principai, nėra absoliutus. Teisès normos draudžia sudaryti sandorius, prieštaraujančius imperatyviosioms įstatymų nuostatoms, valstybèje susiformavusiai viešajai tvarkai ar gerai moralei (viešasis interesas). LAT konstatuoja, kad jei nėra sąžiningai atlyginama, toks susitarimas yra negaliojantis ${ }^{29}$.

\section{Dèl subjekto, kuriam taikomas nekonkuravimo susitarimas}

Nekonkuravimo susitarimu apribojama Konstitucijos 48 straipsnio 1 dalyje ịtvirtinta darbuotojo teisè laisvai pasirinkti darbą, taip pat šis susitarimas, priklausomai nuo jo turinio, gali riboti ir kitą konstitucinị principą - darbuotojo ar kito asmens ūkinès veiklos laisvę ir iniciatyvą (Konstitucijos 46 straipsnis). Kasacinio teismo praktikoje akcentuojama, kad, atsižvelgiant ị tokio susitarimo tikslus, interesų teisètumą, jis negalètų būti sudaromas su bet kuriuo asmeniu (darbuotoju) ${ }^{30}$.

Dažnai tai - vadovaujantys darbuotojai, tačiau vien faktas, kad asmuo eina vadovaujamas pareigas arba ne, savaime nereiškia, kad nekonkuravimo susitarimas atitinkamai gali arba negali būti sudarytas. Ar nekonkuravimo susitarimą buvo galima sudaryti konkrečiu atveju su konkrečiu darbuotoju, turi būti sprendžiama atsižvelgiant ị individualias aplinkybes, ịvertinant darbuotojo pareigų pobūdị ir specifiką, darbe naudojamos informacijos kieki ir svarbą i̇monès veiklai, taip pat veiklos, kurią apima darbuotojo pareigos, santykị su visos įmonès veiklos apimtimi, jo ịgytų žinių ir ịgūdžių reikšmingumą, įtakos konkurencijai realumą ir kt. ${ }^{31}$

Užsienio valstybèse apibrèžiant darbuotojų, su kuriais galima sudaryti nekonkuravimo susitarimus, požymius taikoma ịvairi praktika. Čekijoje toks susitarimas gali būti sudaromas tik su darbuotoju, kuris dirbdamas pas darbdavị sužinojo ir disponavo

28 Supra note 19.

29 Supra note 27.

30 LAT $2007 \mathrm{~m}$. spalio 22 d. nutartis civilinèje byloje UAB ,Docpartner “ v. L. V. Nr. 3K-3-415/2007.

31 Supra note 27. 
informacija, žiniomis, technologiniu ar valdymo know-how, kurių panaudojimas išejus iš darbo galètų smarkiai pakenkti darbdavio verslui; taip pat nustatytos kategorijos darbuotojų, su kuriais nekonkuravimo susitarimai negali būti sudaromi (t. y. pedagogai ir socialiniai darbuotojai); Švedijoje su tam tikrų kategorijų darbuotojais - būtent tais, kurie dirba su svarbia informacija, laikoma verslo paslaptimi; Lenkijoje - su darbuotojais, kurie disponuoja svarbia informacija, kurios panaudojimas gali sukelti didelių nuostolių darbdaviui; Slovėnijoje - su darbuotojais, kurie dirbdami igyja techninių, gamybinių ar verslo žinių bei verslo ryšių; Belgijoje ir Liuksemburge nekonkuravimo susitarimų sudarymo galimybė siejama su darbuotojo darbo užmokesčio dydžiu, o Danijoje tokie susitarimai gali būti sudaromi tik su vadovaujamajị darbą dirbančiais darbuotojais, kuriems buvo patikèta darbdaviui svarbi informacija ${ }^{32}$.

Atsižvelgiant į Lietuvos teismų praktiką ir užsienio patirtị, kiekvienu konkrečiu atveju sudarant nekonkuravimo susitarimą reiktų įsivertinti, ar konkretus darbuotojas gali būti tokio susitarimo subjektas.

\section{Dèl nekonkuravimo susitarimu galiojimo laiko, apimties ir formos}

Nagrinėjant nekonkuravimo susitarimų galiojimo laiką kaip analogiją galima taikyti arba Konkurencijos įstatymo nuostatas, kur nustatyta, kad asmenys, kuriems komercinè paslaptis tapo žinoma dèl jų darbo santykių su ūkio subjektu, gali naudoti šią informaciją praèjus ne mažiau kaip vieneriems metams nuo darbo santykių pasibaigimo, jei šalys nesusitarė kitaip, arba CK nuostatas, taikytinas prekybos agentui, kur nustatyta, kad konkurencijos ribojimas negali būti ilgesnis kaip dveji metai. Mūsų nuomone, nereikètų laikyti šių terminų kaip imperatyvų, galimas ilgesnis nekonkuravimo susitarimo galiojimo terminas kaip vieneri ar dveji metai, tačiau apskritai visas susitarimas turi atitikti protingumo, sąžiningumo ir teisingumo kriterijus. Maksimalus nekonkuravimo susitarimo galiojimo terminas nutraukus darbo sutartį užsienio valstybėse nustatomas ivairiai. Vienose - tai konkretus terminas, nepriklausantis nuo darbuotojo atliekamo darbo pobūdžio (pvz., Čekijoje ir Austrijoje toks terminas negali būti ilgesnis kaip vieni metai; Švedijoje, Latvijoje ir Slovėnijoje - ne ilgesnis nei dveji metai; Italijoje - treji metai). Kitose šalyse šis terminas nustatomas atsižvelgiant ị tai, kokị darbą dirbo (kokias pareigas ejo) darbuotojas (pvz., Rumunijoje nutraukus darbo sutartį nekonkuravimo sąlyga galioja išimtiniais atvejais, bet ne ilgiau kaip šešis ménesius, jeigu ji sudaryta su administracijos darbuotojais, ir ne ilgiau nei dvejus metus su darbuotojais, kurie èjo vadovaujamas pareigas). Dar kitose - konkretus terminas iš viso nenustatomas (pavyzdžiui, Lenkijoje apsiribojama nuostata, kad nekonkuravimo susitarimuose turi būti susitariama dèl nekonkuravimo laikotarpio) $)^{33}$.

Tiek dèl nekonkuravimo susitarimo apimties, tiek dẻl formos (turètų būti rašytinè forma, nes tokios taisyklès ịtvirtintos Čekijoje, Lenkijoje, Latvijoje, Slovėnijoje ir 
Rumunijoje) pritartina R. Krasausko nuomonei, kuris nurodo, kad reiktų vadovautis LAT nuostata, jog nekonkuravimo susitarimas turi atitikti teisingumo, protingumo ir sąžiningumo reikalavimus, minètame susitarime turi būti nustatyta abiejų jos šalių interesų pusiausvyra, o vienos šalies (darbdavio) interesas turi būti ginamas kuo mažiau varžant kitos šalies (darbuotojo) veiksmus. Kaip nurodo R. Krasauskas, reikètų įvertinti ir užsienio valstybėse galiojantị teisinị reguliavimą: Latvijoje konkurencijos draudimas turi apimti tik tas veiklos sritis, kuriose darbuotojas dirbo prieš nutraukiant darbo sutartị, o konkurencijos draudimas, t. y. draudimo rūšis, - apimtis, vieta ir laikas, turi būti nustatomi sąžiningai, atsižvelgiant ị kompensacijos dydį; Čekijoje nekonkuravimo susitarimu galima įpareigoti darbuotoją susilaikyti nuo konkuravimo su darbdaviu dalyvaujant veikloje, kuri būtų tokia pat, kokią darbuotojas atliko prieš nutraukiant darbo sutartį; Slovenijoje ir Rumunijoje nekonkuravimo susitarimas negali būti suformuluotas taip, kad asmeniui būtų užkirstas kelias dirbti visus darbus pagal savo profesiją ir specialybę; Italijoje iš nekonkuravimo susitarimų turi būti aišku, kokioje verslo srityje ir kokioje teritorijoje konkuravimas yra ribojamas, o Austrijoje nekonkuravimo susitarimai galios tik tuomet, jei jie ribos darbuotojo veiksmus darbdavio verslo srityje ${ }^{34}$.

Pažymėtina, kad laiko ir apimties kriterijai tampa vertinamieji kiekvienoje byloje, ir tik nustačius konkrečios bylos aplinkybių visumą, darytinos išvados dẻl konkretaus nekonkuravimo susitarimo teisinès galios.

\section{Dèl nekonkuravimo susitarimų nutraukimo}

Pritartina R. Krasausko nuomonei, kad nustatant nekonkuravimo susitarimų nutraukimo pagrindus turètų būti ịvertinti keli esminiai aspektai:

- galimybè nekonkuravimo susitarimą nutraukti darbdaviui. Šiuo metu, kaip numatyta LAT išaiškinime, darbdavys gali bet kada atsisakyti nekonkuravimo susitarimo ir toks atsisakymas negali būti kvalifikuojamas kaip minèto susitarimo pakeitimas, kadangi laikoma, kad nekonkuravimo susitarimas yra palankus darbdaviui ${ }^{35}$. Panašus teisinis reguliavimas įtvirtintas Latvijoje, o štai Čekijoje nustatyta, kad darbdavys gali atsisakyti nekonkuravimo susitarime prisiimtu ịsipareigojimų (pavyzdžiui, mokèti kompensaciją) tik tuo atveju, jeigu jis darbuotoją įdarbina savo įmonejje;

- galimybé nekonkuravimo susitarimą nutraukti darbuotojui. Čekijoje ir Lenkijoje įtvirtinta galimybė darbuotojui vienašališkai nutraukti nekonkuravimo susitarimą, jeigu darbdavys nesumoka jame numatytos kompensacijos (arba ją moka nesilaikydamas susitarime nustatytos tvarkos);

- darbuotojo atleidimo iš darbo pagrindo įtaka nekonkuravimo susitarimo galiojimui. İvertinę nekonkuravimo susitarimo teisinę prigimtị siūlytumèm nustatyti, kad nekonkuravimo susitarimas galioja tik tuo atveju, jeigu darbo sutartis nu-

34 Krasauskas, R., supra note 5.

35 LAT 2008 m. vasario 20 d. nutartis civilinèje byloje A. G. v. UADBB „,AonLietuva “ Nr. 3K-3-121/2008. 
traukiama dèl darbuotojo kaltės arba darbuotojo pareiškimu be svarbios priežasties $^{36}$.

Taigi šiuo atveju sudarant nekonkuravimo susitarimą svarbu atkreipti dėmesi ị tai, kokiais atvejais toks susitarimas galètų būti nutrauktas ir apskritai nekonkuravimo susitarimo galiojimą sieti su darbo santykių pasibaigimo pagrindu. Juk skirtinga situacija, kai, pavyzdžiui, darbuotojas atleidžiamas dèl jo kaltès ar darbdavio iniciatyva, nesant darbuotojo kaltès.

\section{Dèl netesybų nustatymo už nekonkuravimo susitarimų pažeidimą}

Kaip būdas užtikrinti nekonkuravimo susitarimo laikymąsi yra netesybų nustatymas. Lietuvos teismų praktikai pripažinus, kad nekonkuravimo susitarimas yra civilinė sutartis, atsiveria kelias taikyti sutartinę civilinę atsakomybę netesybų forma. Pavyzdžiui, vienoje byloje situacija buvo tokia, kad 2004 m. lapkričio 23 d. susitarime dèl konfidencialumo (4 punktas) buvo nustatyta, kad E. G., pažeidęs susitarimo dèl konfidencialumo 1 punkte nustatytą konfidencialumo pareigą, privalo sumokèti bendrovei 10000 Lt dydžio baudą ir atlyginti bendrovei visus tokiu pažeidimu padarytus nuostolius (ịskaitant ir negautas pajamas), tiek, kiek jų nepadengia bauda. Kaip nurodyta tame pačiame susitarimo punkte, pajamos, gautos neteisètai naudojant tokią informaciją, laikomos nepagrịstu praturtèjimu ir turi būti grąžinamos bendrovei. Kasacinio teismo teisèjų kolegija, atsižvelgdama ị šioje byloje susiklosčiusias aplinkybes, susitarime dẻl konfidencialumo nurodytos konfidencialios informacijos pobūdị, sprendè, jog ieškovo naudai priteistinas 24000 Lt žalos atlyginimas. Nurodytą sumą sudaro 10000 Lt bauda, nustatyta susitarime dèl konfidencialumo (kuri priteistina iš atsakovo E. G., šiam pažeidus susitarimą dèl konfidencialumo) ir ... nuostoliai ${ }^{37}$. Kitoje byloje nustatyta, kad konfidencialumo sutarties 2 punkte nurodyta, kad, nustačius faktinio ar realiai grèsusio šios sutarties pažeidimo faktą, darbuotojas įsipareigoja sumokèti trijų paskutinių mėnesių išmokètų atlyginimų sumos dydžio baudą, taip pat kompensuoti visus dẻl šio pažeidimo bendrovès patirtus nuostolius. Nustatęs šalių konfidencialumo sutarties pažeidimo faktą, apeliacinès instancijos teismas turèjo teisini pagrindą tenkinti atsakovo priešieškinio reikalavimus dèl baudos priteisimo ${ }^{38}$.

Kaip nurodo R. Krasauskas, Čekijos darbo kodekse nustatyta galimybė susitarti dèl baudos (baudos dydis turi būti proporcingas ir atitikti susitarimu sulygtus ịsipareigojimus), kurią privalo sumokèti šị susitarimą pažeidęs darbuotojas, o sumokèjęs tokią baudą darbuotojas atleidžiamas nuo visų susitarimu prisiimtų įsipareigojimų vykdymo ${ }^{39}$.

\footnotetext{
36 Krasauskas, R., supra note 5.

37 LAT $2012 \mathrm{~m}$. birželio 26 d. nutartis civilinèje byloje UAB ,Diteilas “ v. UAB ,, Chemika ir E.G. “ Nr. 3K$3-326 / 2012$.

38 LAT $2011 \mathrm{~m}$. rugsèjo $26 \mathrm{~d}$. nutartis civilinèje byloje $J$. V. v. UAB ,Arijus “ Nr. 3K-3-354/2011.

39 Krasauskas, R., supra note 5.
} 
Apibendrintai galime teigti, kad Lietuvos teisèje netesybos būtų tinkamas būdas nekonkuravimo susitarimo vykdymui užtikrinti, tik, žinoma, netesybų dydis turètų atitikti teisingumo, protingumo ir sąžiningumo kriterijus.

\section{Dèl nekonkuravimo susitarimų reglamentavimo}

Išanalizavus aspektus, kurie aptartini sudarant nekonkuravimo susitarimus, kyla klausimas, kokias normas reiktų ittvirtinti, siekiant reglamentuoti nekonkuravimo susitarimų sudarymo taisykles, kartu užpildant šią teisès spragą. Šiuo atveju aktualu atsižvelgti ị užsienio šalių patirtį.

Olandijoje ị darbo sutartis įtraukiamos konkurencijos draudimo pasibaigus darbo santykiams sąlygos gana dažnos. Reikalavimai tokioms sąlygoms pagal Olandijos civilinį kodeksą nèra griežti - rašytinè forma ir darbuotojo pilnametystė. Tačiau Olandijos parlamente 2002 metų pradžioje priimtas teisès aktas numato papildomą ịpareigojimą darbdaviui mokèti teisingą atlyginimą už tokios sąlygos galiojimo laikotarpį. Lenkijoje konkurencijos draudimo sąlygas reguliuoja Darbo kodeksas. Sutartis dèl draudimo konkuruoti su darbdaviu esant darbo santykiams gali būti sudaroma su kiekvienu darbuotoju be jokių ribojimų. Tačiau sutartys dèl konkurencijos draudimo po darbo sutarties pasibaigimo gali būti sudaromos tik su darbuotojais, dirbančiais su informacija, kurios paskleidimas galètų sukelti darbdaviui nuostolių. Sudaręs sutartį dèl konkurencijos draudimo po darbo sutarties pasibaigimo, darbdavys Lenkijoje ịpareigojamas mokèti darbuotojui atlygị, ne mažesnį negu 25 procentai sumos, kurią darbuotojas gautų dirbdamas per sutarties galiojimo laiką. Belgijoje konkurenciją draudžiančias sutartis galima sudaryti ne ilgiau nei vieneriems metams, tik Belgijos teritorijoje ir tik su darbuotoju, per metus uždirbančiu daugiau nei 25000 eurų. Vokietijoje tokios sutartys pagal teismų praktikoje suformuotas taisykles sudaromos ne ilgesniam nei dvejų metų laikotarpiui, darbuotojui mokamas atlygis, ne mažesnis negu 50 proc. sumos, kurią gautų darbuotojas dirbdamas per sutarties galiojimo laiką ${ }^{40}$.

Kaip matome, skirtingose užsienio valstybėse teisinis reglamentavimas labai skirtingas. Doc. R. Krasauskas siūlo ịtvirtinti gana didelès apimties nekonkuravimo susitarimus reglamentuojančias normas Darbo kodekse: 1) prielaidas nekonkuravimo susitarimui sudaryti (t. y. apibrèžti darbuotojų, su kuriais tokie susitarimai gali būti sudaromi, požymius, kurie tiesiogiai turètų priklausyti nuo atliekamų darbo funkcijų ar einamų pareigų pobūdžio; darbuotojui nustatyti sąžiningą ir teisingą kompensaciją, minimalų jos dydị bei mokejjimo būdus); 2) nekonkuravimo susitarimo galiojimą laike ir erdvèje; 3) nekonkuravimo susitarimo formą (tokie susitarimai turètų būti sudaromi raštu); 4) nekonkuravimo susitarimo nutraukimo ypatumus (tai reguliuojant turètų būti ịvertinta galimybé šị susitarimą nutraukti darbdaviui, darbuotojui, taip pat darbuotojo atleidimo iš darbo pagrindo įtaka nekonkuravimo susitarimo galiojimui) ${ }^{41}$.

40 Petravičiūtè, A., supra note 10.

41 Krasauskas, R., supra note 5. 
Nagrinėjant nekonkuravimo susitarimus verslo perleidimo atveju V. Bitè laikosi nuomonės, kad nekonkuravimo susitarimai turètų būti pripažinti teisètais (leistinais), jeigu atitinka dvi sąlygas: apribojimų tikslas yra teisètas ir apribojimai yra proporcingi (protingi) jų trukmès, dalyko (turinio), geografinès teritorijos ir subjektų atžvilgiü ${ }^{42}$.

Mūsų nuomone, nekonkuravimo susitarimus reiktų reglamentuoti Lietuvos teisès aktuose ir užpildyti šią spragą. Dèl to rinkos dalyviams atsirastų didesnis teisinis tikrumas dèl galimybės sudaryti nekonkuravimo susitarimą. Manome, kad aktualu reglamentuoti nekonkuravimo susitarimų sudarymą pasibaigus darbo santykiams ir tai nustatyti Konkurencijos įstatyme. Siekiant išvengti kazuistinio reglamentavimo, manytume, kad tikslinga įtvirtinti tik bazinius šio susitarimo principus, o kitas sąlygas palikti pačioms šalims. Kilus ginčui tarp darbuotojo ir darbdavio teismas įvertintų visa apimtimi susitarimą, palikdamas ji galioti arba pripažindamas negaliojančiu. Mūsų nuomone, pakaktų įstatyme ịtvirtinti, kad toks susitarimas turètų būti sudaromas rašytine forma, pasibaigus darbo santykiams nustatant ne ilgesni kaip dvejų metų laikotarpi ir sąžiningą kompensaciją, ne mažesnę nei 25 procentai nuo buvusio darbuotojo vidutinio darbo užmokesčio. Kitas sąlygas paliktume nusistatyti pačioms šalims, atsižvelgiant ị protingumo, sąžiningumo ir teisingumo principus.

\section{Dèl Konkurencijos ịstatymo taikymo ribu}

Konkurencijos įstatymas numato, kad ūkio subjektas, kurio teisèti interesai pažeidžiami nesąžiningos konkurencijos veiksmais, turi teisę kreiptis ị teismą su ieškiniu dèl neteisètų veiksmų nutraukimo, padarytos žalos atlyginimo. Konkurencijos įstatyme taip pat nustatyta, kad buvę darbuotojai negali naudoti buvusio darbdavio komercinių paslapčių anksčiau nei praėjus metams nuo darbo sutarties pabaigos, nebent įstatymai ar sutartis nustato kitą terminą ${ }^{43}$. Šiuo atveju kyla klausimas, kiek pagal Konkurencijos įstatymą byloje dèl nesąžiningos konkurencijos atsakovu savarankiškai gali būti pats darbuotojas, jei su juo nėra sudaryto susitarimo dèl nekonkuravimo, nes įstatymas apsaugą sieja su nesąžiningais ūkio subjekto veiksmais. Galime skirti atvejus, 1) kai buvęs darbuotojas tampa kito ūkio subjekto vadovu ar dalyviu (pavyzdžiui, akcininku), ir atvejị, 2) kai buvęs darbuotojas su kitu ūkio subjektu yra sudaręs tik darbo sutartị, tačiau nèra nei to ūkio subjekto dalyvis, nei vadovas.

Pirmuoju atveju LAT yra pripažinęs, kad atsakovu tokioje byloje gali būti tiek buvęs darbuotojas, tiek ūkio subjektas. Pavyzdžiui, UAB „Baldų rojus“ generalinio direktoriaus $2003 \mathrm{~m}$. kovo $27 \mathrm{~d}$. icsakymu Nr. 13 buvo patvirtintas naujas bendrovès komercinių paslapčių sąrašas. Komercine paslaptimi buvo pripažinti sutarčių su Lietuvos ir užsienio prekių ir paslaugų tiekèjais ypatumai, sąlygos, mokejjimo sąlygos, šalių ìsipareigojimai ir vykdymas, prekybiniai antkainiai, sutartinės kainų nuolaidos, prekių ir paslaugų savikaina, kainų nustatymo metodika ir kt. Su šiuo sąrašu atsakovas buvo 
supažindintas pasirašytinai. 2004 m. bendrovèje „Baldų rojus“ labai sumažějo baldų, gaminamų įmonèje „Angstrem-Arredo“, pardavimų skaičius. Ieškovas sužinojo, kad iš esmės identiškais baldais (skiriasi tik jų pavadinimai), bet kur kas mažesnėmis kainomis pradejjo prekiauti UAB „,Sidabrinis delfinas“. Taigi atsakovas, kad gautų asmeninę naudą, nesąžiningai, neteisètai panaudojo bendrovès „Baldų rojus“ komercinę paslaptị apie įmonès „Angstrem-Arredo“ baldų savikainą ir apyvartą, UAB „Baldų rojus“ taikomo prekybinio antkainio dydį, UAB „Baldų rojus“ ir įmonės „Angstrem-Arredo“ bendradarbiavimo, mokejimo gamintojui sąlygas. Tinkamas prekių asortimento formavimas, jo struktūra ir proporcijos yra vienas iš esminių sẻkmingos prekybos baldais faktorių. Kad surinktų, susistemintų šią informaciją, ieškovas kasmet skiria didelius finansinius išteklius. Teismas konstatavo, kad savo privatų verslą atsakovas organizavo atsižvelgdamas ị informaciją, sudarančią UAB „Baldų rojus“ komercinę paslaptį. Ši informacija suteikė galimybę įvertinti privataus verslo rentabilumą ir rizikos koeficientą. Teismas padare išvadą, kad atsakovas nuo $2004 \mathrm{~m}$. vasario $11 \mathrm{~d}$. iki $2004 \mathrm{~m}$. spalio $22 \mathrm{~d}$. neteisètai naudojosi ieškovo komercinę paslaptị sudarančia informacija savo privačioje veikloje ${ }^{44}$.

Antruoju atveju LAT pasisake kitaip. LAT pažymëjo, kad Konstitucijos 46 straipsnio 4 dalyje įtvirtinta, kad ịstatymas saugo sąžiningos konkurencijos laisvę. Konkurencijos laisvė garantuoja teisę ūkio subjektams pasirinkti priemones, kuriomis jie konkuruoja, tačiau ši teisè nèra absoliuti - ją iggvendinant negalima pažeisti kitų subjektų teisių ir teisètų interesų. Tik sąžininga konkurencija užtikrina ekonominę pažangą, todèl teisès normų draudžiami nesąžiningos konkurencijos veiksmai. Kasaciniame skunde buvo nurodoma, kad atsakovai atliko nesąžiningos konkurencijos veiksmus kasatoriaus atžvilgiu, taip atsakovè (buvusi darbuotoja) pažeidè nekonkuravimo susitarimu bei konfidencialumo sutartimi prisiimtus ịsipareigojimus, o atsakovas (imonè, darbdavys) - Konkurencijos įstatymo reikalavimus, nes nepaisė draudimo atlikti bet kokius veiksmus, prieštaraujančius ūkinès veiklos sąžiningai praktikai ir geriems papročiams, kai tokie veiksmai gali pakenkti kito ūkio subjekto galimybėms konkuruoti. Kasatoriaus teigimu, atsakovas, pradėdamas vykdyti konkuruojančią veiklą, pasinaudojo atsakovès darbo pas ieškovą metu įgytais verslo ryšiais, praktine patirtimi ir kita komercine informacija bei taip ịgijo nepagrịstą konkurencini pranašumą. Teisèjų kolegija pažymèjo, kad nesąžininga konkurencija gali būti konstatuojama tik nustačius, kad subjektui įstatymas ar šalių susitarimas draudė konkuruoti, taip pat ịrodžius, jog draudžiami veiksmai buvo atlikti. Konkurencijos įstatymo 1 straipsnio 2 dalyje nustatyta, kad šis įstatymas reglamentuoja konkurenciją ribojančią ar galinčią riboti viešojo administravimo subjektų bei ūkio subjektų veiklą ir nesąžiningos konkurencijos veiksmus, nustato šiu subjektų teises, pareigas ir atsakomybę bei konkurencijos ribojimo ir nesąžiningos konkurencijos kontrolès Lietuvos Respublikoje teisinius pagrindus. Iš Konkurencijos įstatymo 2 straipsnio 1, 2 daliu, taip pat 3 straipsnio 4 dalies normų matyti, kad jo nuostatos taikytinos ūkio subjektams. Taigi, atsakovei D. S. Konkurencijos įstatymo nuostatos netaikytinos, nes ji nelaikytina ūkio subjektu pagal Konkurencijos ịstatymą (Konkuren- 
cijos įstatymo 3 straipsnio 4 dalis $)^{45}$. Taigi šiuo atveju teismų praktika tampa neaiški, išskirianti buvusį darbuotoją kaip tinkamą ir netinkamą atsakovą, priklausomai nuo jo teisinių santykių pobūdžio su ūkio subjektu, jei buvęs darbuotojas perduoda komercinę paslaptị ūkio subjektui. Mūsų manymu, tokia praktika siaurina normos taikymą ir yra nepagrịsta, nes nepagrịstai ginamas asmuo, kuris padeda ir prisideda prie kito ūkio subjekto nesąžiningos konkurencijos. Tokiu atveju darbuotojai skatinami nesteigti įmonių tiesiogiai (jas steigti per kitus asmenis), o tik ịsidarbinti, taip siekiant išvengti atsakomybės už komercinès paslapties atskleidimą ir jos naudojimą ūkio subjekto veikloje. Šiuo atveju tikslintina arba teismų praktikoje aiškintina ūkio subjekto samprata, kuri numatyta Lietuvos Respublikos konkurencijos įstatyme.

\section{Išvados}

Nekonkuravimo susitarimai tarp darbdavio ir darbuotojo laikytini civiliniais susitarimais, reguliuojamais civilinės teisès normų, išskyrus atvejus, kai konkuruojama darbo santykių metu.

Kadangi pagal Konstituciją riboti žmogaus teises ir laisves galima, jeigu yra laikomasi šių sąlygų: tai daroma įstatymu; ribojimai yra būtini demokratinèje visuomenèje siekiant apsaugoti kitų asmenų teises bei laisves ir Konstitucijoje įtvirtintas vertybes, taip pat konstituciškai svarbius tikslus; ribojimais nėra paneigiama teisių ir laisvių prigimtis bei jų esmé; laikomasi konstitucinio proporcingumo principo, manytume, kad LAT praktika, pripažindama sutarčių laisvès principą ir nekonkuravimo susitarimų galimumą bei pasiremdama Civilinio kodekso normomis, nepaneigè konstitucinès teisès laisvai pasirinkti darbą, dar kartą patvirtindama, kad konstitucinės teisès nèra absoliučios.

Kad nekonkuravimo susitarimai, sudaromi tarp darbuotojų ir darbdavių, būtų galiojantys, jie turi neprieštarauti imperatyvioms įstatymo normoms, gerai moralei ir atitikti teismų formuojamas jų sudarymo taisykles.

Nekonkuravimo susitarimas sudaromas laisva darbdavio ir darbuotojo valia, kai darbdavys, atsižvelgdamas į nekonkuravimo įsipareigojimų apimtį (t. y. kaip šie įsipareigojimai apriboja darbuotojo galimybes susirasti darbą ir gauti pakankamas pajamas) moka darbuotojui tinkamą kompensaciją. Nekonkuravimo susitarimai yra negaliojantys, jei darbuotojui nėra mokama teisinga ir tinkama kompensacija. Kompensacija už nekonkuravimą negali būti įtraukta ị darbo užmokestị, nes darbo užmokestis yra atlyginimas už darbą, darbuotojo atliekamą pagal darbo sutartị.

Sudarant nekonkuravimo susitarimus rekomenduojama susitarti dèl šių sąlygų: įvertinti darbuotojų, su kuriais tokie susitarimai gali būti sudaromi, požymius; nustatyti tinkamą ir teisingą kompensaciją, įskaitant jos dydị bei mokèjimo tvarką; nustatyti nekonkuravimo susitarimo galiojimo laiką; nustatyti nekonkuravimo susitarimo galiojimo apimtị (erdvę); įsivertinti nekonkuravimo susitarimo formą (paprasta rašytine forma 
arba tvirtinama notaro); nustatyti nekonkuravimo susitarimo nutraukimo atvejus (galimybé ši susitarimą nutraukti darbdaviui, darbuotojui, taip pat darbuotojo atleidimo iš darbo pagrindo įtaka nekonkuravimo susitarimo galiojimui); nustatyti sankcijas už nekonkuravimo susitarimo nesilaikymą. Visi kriterijai tampa vertinamieji kiekvienoje byloje, ir tik nustačius konkrečios bylos aplinkybių visumą, darytinos išvados dèl konkretaus nekonkuravimo susitarimo teisinès galios.

Nekonkuravimo susitarimus reiktų reglamentuoti teisès aktuose, siekiant užpildyti šią spragą, kad rinkos dalyviams atsirastų didesnis teisinis tikrumas dèl galimybès sudaryti nekonkuravimo susitarimus. Aktualu reglamentuoti nekonkuravimo susitarimų sudarymą pasibaigus darbo santykiams, nes manome, kad darbo santykių metu taikomos Darbo kodekso normos ir principai. Naują reglamentavimą rekomenduotina nustatyti Lietuvos Respublikos konkurencijos įstatyme.

Siūlytina, kad pagal teisès normas nekonkuravimo susitarimas būtų sudaromas rašytine forma, pasibaigus darbo santykiams šalims nustatant ne ilgesnị kaip dvejų metų laikotarpi ir darbdaviui mokant tinkamą kompensaciją, ne mažesnę nei 25 procentai nuo buvusio darbuotojo vidutinio darbo užmokesčio. Kitas sąlygas palikti nusistatyti pačioms šalims, atsižvelgiant ì protingumo, sąžiningumo ir teisingumo principus.

Teismų praktika tampa neaiški, išskirianti buvusi darbuotoją kaip tinkamą ir netinkamą atsakovą bylose dẻl nesąžiningos konkurencijos dẻl komercinès paslapties atskleidimo, priklausomai nuo jo teisinių santykių pobūdžio su ūkio subjektu (dalininkas, vadovas ar darbuotojas). Mūsų manymu, tokia praktika siaurina normos taikymą ir yra nepagrịsta, nes nepagrịstai ginamas asmuo, kuris padeda ir prisideda prie kito ūkio subjekto nesąžiningos konkurencijos.

\section{Literatūra}

Bagdanskis, T., et al. Darbo teisé. Vadovėlis. Vad. G. Dambrauskienè. Vilnius: Mykolo Romerio universiteto Leidybos centras, 2008.

Bite, V. Non-Competition convenants in case of a business transfer. Jurisprudencija. 2011, 18(1): 177-198.

Bužinskas, G., et al. Darbo teisè. Vadovèlis. Vad. I. Nekrošius. Vilnius: Teisinès informacijos centras, 2008.

Dambrauskienè, G. Civilinių ir darbo sutarčių sąveika. Jurisprudencija. 2002, 28(20): 7.

Davulis, T. Nekonkuravimo susitarimai Lietuvos darbo teisèje. Juristas. 2006, 4.

Davulis, T. Nekonkuravimo susitarimai Lietuvos darbo teisèje. Juristas. 2006, 5.

Europos teisès departamento prie Lietuvos Respublikos Vyriausybès $2003 \mathrm{~m}$. rugpjūčio
5 d. išvada Nr. IXP-2593 [interaktyvus]. [žiūrèta 2013-06-16]. <http://www3.lrs.lt/pls/inter3/dokpaieska.showdoc_1?p_id=219891>.

Krasauskas, R. Nekonkuravimo susitarimai darbo teiseje. Ar darbuotojas ir darbdavys lygiaverčiai konkurentai? Jurisprudencija. 2008, 8(110): 41-49.

Lietuvos Respublikos Konstitucija. Valstybès žinios. 1992, Nr. 33-1014.

Lietuvos Respublikos darbo kodeksas. Valstybes žinios. 2002, Nr. 64-2569.

Lietuvos Respublikos darbo sutarties įstatymas. Valstybès žinios. 1991, Nr. 36-973.

Lietuvos Respublikos civilinis kodeksas. Valstybès žinios. 2000, Nr. 74-2262.

Lietuvos Respublikos konkurencijos įstatymas. Valstybès žinios. 1999, Nr. 30-856.

Lietuvos Respublikos prekybos įstatymas. Valstybès žinios. 1995, Nr. 10-204. 
Lietuvos Respublikos darbo kodekso projektas. 2003, Nr. IXP-2593 [interaktyvus]. [žiūrèta 2013-06-16]. <http://www3.lrs.lt/pls/inter2/ dokpaieska.showdoc_1?p_id=211505>.

Lietuvos Respublikos Seimo kanceliarijos Teisès departamento $2003 \mathrm{~m}$. gegužès $28 \mathrm{~d}$. išvada Nr. IXP-2593 [interaktyvus]. [žiūrèta 2013-06-16]. <http://www3.lrs.lt/pls/inter3/ dokpaieska.showdoc_1?p_id=211780>.

Lietuvos Respublikos darbo kodekso 18.2, 52.1, 56.2, 59.2, 60, 90, 127.3, 184.2, 256.1, 268 straipsnių pakeitimo, 42.4 p., 52.2, $89.1,129.4,132,135,145$ straipsniu pripažinimo netekusiais galios ir 21(1), 107(1) straipsnių papildymo ìstatymo projektas Nr. DCP-2593 [interaktyvus]. [žiūrèta 201306-16]. <http://www3.Lrs.lt>.

Nekrošius, I.; Nekrošius, V.; Vèlyvis, S. Roménu teise. Vilnius: Justitia, 1999, p. 245.

Petravičiūtè, A. Nekonkuravimo susitarimai tarp darbuotojo ir darbdavio: esmè ir teisinio reguliavimo ypatumai. Teise. 2007, 65: 144-150.

Tatol, R. Nekonkuravimo susitarimų su imonių darbuotojais sudarymo tvarka ir igyvendinimas. Societal Innovations for Global Growth. 2012, 1 (1): 949-961.

Tiažkijus, V. Darbo teisé: teorija ir praktika. Vilnius: Justitia, 2005.

Vaišvila, A. Teisès teorija. Vadovèlis.Vilnius: Justitia, 2004.

Vaišvila, A. Teisès teorija. Vadovèlis. Vilnius: Justitia, 2009, p. 438-440.

Lushnikov, A. M.; Lushnikov, N. V. Kurs trudovogo pravo. Tom 1. Moskva: Statut, 2009, s. 70-714.

Lietuvos Respublikos Konstitucinio Teismo $2002 \mathrm{~m}$. kovo $14 \mathrm{~d}$. nutarimas [interaktyvus]. [žiūrèta 2013-06-16]. <http://www.lrkt.lt/ dokumentai/2002/n020314.htm>.
Lietuvos Respublikos Konstitucinio Teismo $2002 \mathrm{~m}$. lapkričio $25 \mathrm{~d}$. nutarimas [interaktyvus]. [žiūrèta 2013-06-16]. <http://www. lrkt.lt/dokumentai/2002/n021125.htm>.

LAT $2003 \mathrm{~m}$. birželio $5 \mathrm{~d}$. nutartis civilinèje byloje D. Baliūnas v. UAB , Kemira GrowHow" Nr. 3K-7-408/2003.

LAT $2005 \mathrm{~m}$. vasario $14 \mathrm{~d}$. nutartis civilinèje byloje $U A B$,Filana“ v. R. J. Jančauskas Nr. 3K-3-65/2005.

LAT $2007 \mathrm{~m}$. gegužès $8 \mathrm{~d}$. nutartis civilinèje byloje $U A B$,Baldu rojus “ v. G. O. Nr. 3K3-197/2007.

LAT $2007 \mathrm{~m}$. spalio $22 \mathrm{~d}$. nutartis civilineje byloje $U A B$,Docpart-ner" v. L. V. Nr. 3K-3$415 / 2007$.

LAT $2008 \mathrm{~m}$. vasario $20 \mathrm{~d}$. nutartis civilinejje byloje A. G. v. UADBB ,AonLietuva “ Nr. 3K-3$121 / 2008$.

LAT $2011 \mathrm{~m}$. liepos $1 \mathrm{~d}$. nutartis civilinèje byloje R. D. v. UAB „Putokšnis “ Nr. 3K-3$303 / 2011$.

LAT $2011 \mathrm{~m}$. rugsèjo $26 \mathrm{~d}$. nutartis civilinèje byloje J. V. v. UAB „Arijus “ Nr. 3K-3$354 / 2011$.

LAT $2011 \mathrm{~m}$. spalio $4 \mathrm{~d}$. nutartis civilinejje byloje E. D. B. v. UAB , Žaibo ratas Vilnius “ ir kiti Nr. 3K-3-366/2011.

LAT $2012 \mathrm{~m}$. birželio $8 \mathrm{~d}$. nutartis civilinèje byloje $U A B$,Miesto energija “ v. J. A. K. Nr. 3K-3-255/2012.

LAT $2012 \mathrm{~m}$. birželio $26 \mathrm{~d}$. nutartis civilinèje byloje UAB ,Diteilas “ v. UAB ,Chemika ir E. G. "Nr. 3K-3-326/2012.

LAT $2012 \mathrm{~m}$. lapkričio $12 \mathrm{~d}$. nutartis civilinèje byloje $R$. S. v. UAB ,ETB Legal “ Nr. 3K-3476/2012.

LAT $2013 \mathrm{~m}$. birželio $28 \mathrm{~d}$. nutartis civilinèje byloje $U A B$, ,JG reklamos dovanos " v. D. $S$. ir UAB , Verslo inkorporacijos centras " Nr. 3K-3-377/2013.

LAT $2013 \mathrm{~m}$. liepos $5 \mathrm{~d}$. nutartis civilineje byloje $U A B$, ,Marilita" v. A. B. ir R. Č. Nr. 3K3-401/2013. 


\title{
PROBLEMS OF APPLICATION OF EMPLOYEE'S DUTY NOT TO COMPETE
}

\author{
Tomas Bagdanskis
}

Mykolas Romeris University, Lithuania

Summary. As there is a gap of legal regulation of covenants not to compete in Lithuania, the legal doctrine and the case-law are analyzed in this article. It is recognized in judicial practice that labour laws are not applicable for the regulation of the covenants not to compete. So, the parties, an employer and employee, are free to make agreement on non-competition.

There are some suggested principles how to make parties' agreement on non-competition. Firstly, there should be disputed an adequate compensation to the restrictions that would be made for an employee. Secondly, the restriction of competing should be precisely described, taking into account other issues, such as period of non-competing, employee's qualification and duties, termination of agreement, etc.

It is also proposed to supplement the Law on Competition of the Republic of Lithuania with the rules concerning the conclusion, execution or termination of these covenants.

Keywords: employee, employer, non-competition, covenant not to compete, employment contract, employment relationship, civil relationship.

Tomas Bagdanskis, Mykolo Romerio universiteto Teisès fakulteto Verslo katedros docentas, socialinių mokslų (teisès krypties) daktaras. Mokslinių tyrimų kryptys: darbo teisè, ES darbo teisė.

Tomas Bagdanskis, Mykolas Romeris University, Faculty of Law, Department of Bussines Law, Associate Professor, Doctor of Social Sciences (Law). Research interests: labour law, EU labour law. 